\title{
LEARNING TO WRITE INSTRUCTIONS: IMPLEMENTATION OF 21st CENTURY LIFE SKILLS INNOVATION
}

\author{
Yohanis Hukubun, Iwan Rumalean, \& Everhard M. Solissa \\ Indonesian Language and Literature Education Study Program, \\ FKIP Pattimura University Ambon \\ Email: iwan197577@gmail.com
}

\begin{abstract}
This paper aimed to describe learning to write as part of $21^{\text {st }}$ century life skills. Writing as basic literacy is the main material in the 2013 curriculum. One type of writing is writing instructions which require the abilities and skills acquired from educational institutions to be applied in everyday life. Writing instructions is one of the four language skills should be mastered by students. Therefore, Indonesian language teachers are required to master the material for writing instructions both theoretically and practically. Theoretically, it explained about the meaning of writing, types of writing, writing instructions. Practically, they were implemented in learning according to Regulations of the Minister of Education and Culture Number 22 of 2016 and Number 103 of 2014 concerning on standard process. In those regulations, it is explained about graduate competency standards, syllabus, and lesson plan. The first step that needs to be done before preparing the lesson plan is to analyze the graduate competence standard (GCS). After analyzing the GCS, it is then translated into a syllabus. Furthermore, the writing of lesson plans developed from the syllabus to be a direction of learning in achieving basic competencies. This paper was the result of the collaboration of the community service group of Faculty of Teacher Training and Education of Unpatti in South Buru Regency in 2021.
\end{abstract}

Keywords: learning, writing instructions, life skills.

\section{Introduction}

Instructions are important in human life in today's technological era where some activities are carried out on line. Like online shopping, Gojek, Go food, online haircuts, education enrollment and work is done on line. Because the activity is on line, usage instructions are needed to make it easier for customers. Otherwise, off line activities such as sleeping, eating, walking, resting, sitting, exercising, worshiping, and studying, are done based on certain instructions.

Instructions for on line activities are used in written form. While the activities carried out off line, there are two forms of instructions, namely written and oral instructions. Oral instructions generally have become a community convention. Oral instructions in Indonesia are often found in local wisdom products such as customary law. Examples of customary law in Maluku Province are Sasi (known in Central 
Maluku Regency), and Ngam law (known in Eastern Seram Regency). Sasi or Ngam have certain procedures that have become verbal conventions and have been passed down from generation to generation since the ancestors. In addition to oral instructions, there are also written instructions as found in health products such as procedures for caring dental health, for maintaining eye health, and for taking medicine. Instructions are also found for ready-to-eat food products, such as the procedure for cooking noodles. Take a look at the following examples of instructions (Sholeh, 2020).

\section{a. Steps to create an e-mail account (Gmail)}

1. Open a browser and type Gmail.com in the address bar.

2. Click the Create account menu and select the option for yourself.

3. Fill in your personal data form provided such as First Name, Last Name, User Name, Password and Confirmation on the Create Google Account. If it's been done, click the Next button.

4. Enter Phone Number (optional), Recovery Email Address (optional), Date of Birth (required) and Gender (required). If it's been done, click the Next button.

5. Click the "I agree" button on the Privacy and Terms page.

6. Done, your New Gmail account is ready to be used.

\section{b. Hand Washing Instructions from The Indonesian Ministry of Health}

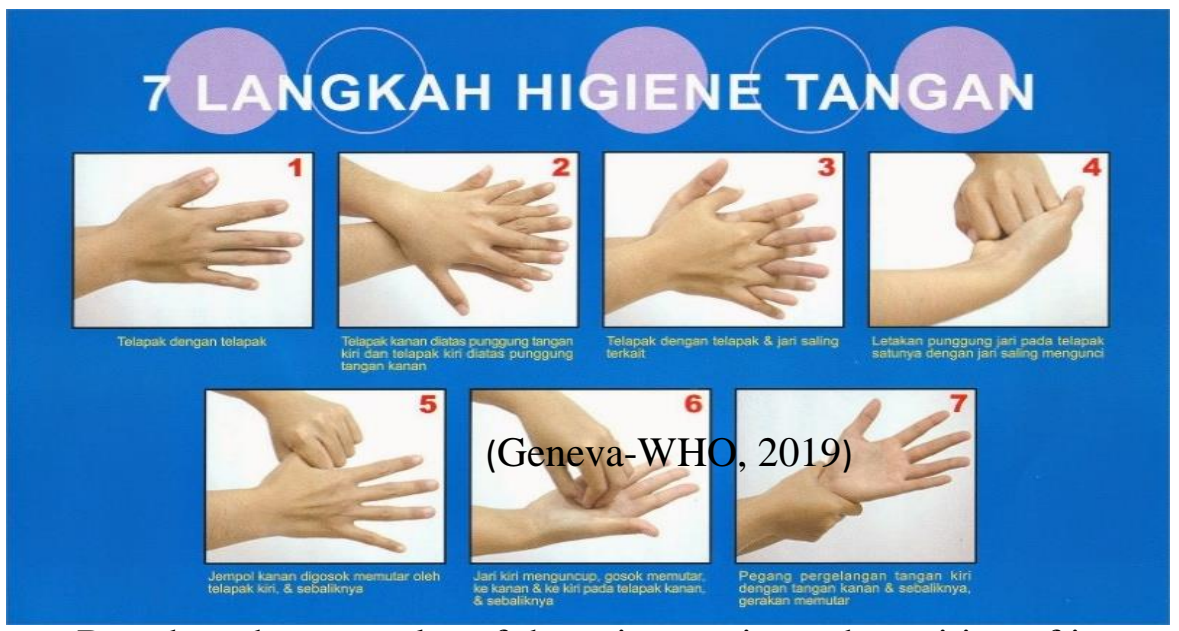

Based on the examples of those instructions, the writing of instructions should be ordered by steps or the correct order of procedures. In addition, it needs to be equipped with pictures or illustrations so that users have no trouble using those instructions. In terms of language, it is necessary to use effective sentences so that they are easily understood by readers.

Instructions in today's digital era are so important that the government accommodates them in the 2013 curriculum with the terms of writing instructions or writing procedures. As mentioned, that there are three abilities should be possessed by students, namely (1) character, (2) competence, and (3) literacy. In terms of character abilities, students are expected to be able to face a changing environment at 
any time. In terms of competence, they are expected to be able to overcome every challenge they face. In terms of literacy, they are expected to be able to apply core competencies in everyday life (Harosid, 2017). Through these three abilities, students are expected to be able to face the challenges of the disruptive $21^{\text {st }}$ century.

Based on this explanation, writing instructions is part of basic literacy which is the main material in the 2013 curriculum. Literacy point requires that the abilities and skills obtained from educational institutions must be applied in everyday life. Thus, writing instructions as basic literacy is one of the skills that guarantee life skills opportunities in the $21^{\text {st }}$ century. Writing instructions is one component of the four language skills should be mastered by students. Therefore, Indonesian language teachers are required to master the material for writing instructions both theoretically and practically.

\section{Discussion \\ Writing}

Language skills consist of four, namely (1) listening, (2) speaking, (3) reading, and (4) writing. Writing instructions is part of the writing skill which is the fourth ability to be mastered after the other three skills. Students and teachers need to master writing skills well. Teachers are required, in addition, to mastering the theory and practice of writing. They must also master the science of pedagogy well, for example the use of learning media (Rumalean, 2014:59-74). Thus teachers are able to teach their students well, and students will also have a good learning experience.

Theoretically, Mulyati et.al (2010) explain that writing is an activity to describe the graphicization of speech between two or more parties with the aim that each party understands the purpose of communication through graphic symbols. The symbols referred to graphic symbols that have gone through conventions. The symbols used in writing activities are not symbols that are only understood by one party, such as the author or the reader, but those that can be understood by both the author and the reader.

Writing is a language skill that can produce products. If someone writes a guide about saving oneself during an earthquake, then the product is a safety manual during an earthquake. Likewise with instructions on the procedure for taking medicines from doctors, the products are instructions for taking medicines. Therefore, writing is categorized as a productive language skill along with speaking. Meanwhile, listening and reading skills are considered as receptive language skills. However, the four language skills should be mastered well by students (Rumalean, 2014:17-27).

\section{Hint}

Instructions can be found in the house to outside on the highway. There are many instructions that intend to give directions or procedures for doing something to people in need. Examples of instructions outside the house include traffic signs, announcements for sports tournaments enrollment, instructions for prospective new students' admission, instructions for new students' admission, instructions for 
prospective soldiers' enrollment, or instructions for registration of employee recruitment.

Instructions for doing something, using something, and making something contain steps or procedures that should be done. In the world of learning, especially learning to write, teachers teach students to be able to take the steps to write a job or activity, then procedures for using the tools and materials needed in the work. Next, the students do the activity of writing instructions. Writing assignments given by the teacher can be in the form of groups or individuals (Suyatno, 2004:94-95). Thus, writing instructions is important because it is almost used in every aspect of human life.

\section{Writing Instructions}

Based on the explanation of writing and using the instructions in points 1 and 2 , it is concluded that writing is an activity of human thought containing certain messages which are symbolized through graphics that are understood by both writer and reader. While instructions are messages that contain steps, procedures or sequences in doing something, doing something, and making something. Thus, writing instructions is an interactive communicative activity between writers and readers by using graphic symbols that are agreed upon (conventions) and are understood with certain steps or procedures so that people (readers) can do something right.

Writing the instructions at least consists of several phases, namely (1) preparation phase, (2) writing instructions, and (3) finishing (Scoggins, 2016). In preparation phase, a writer prepares all things related to writing instructions, for example, the target of the instructions to be conveyed. If the intended targets are professionals, the most important point is the meaning conveyed clearly not the detailed instructions; the use of effective language; not long-winded; and if necessary, the use of pictures will need to be prepared. In addition, use words that are more familiar to readers like you or your brother, and don't forget to use active verbs such as done, played, and published, and the sentence used should be a command sentence such as "add enough sugar or stir until cooked".

After the first phase is ready, then the next step is the phase of writing instructions. In this phase, the writer immediately writes instructions, starting with the first clue or number one, then the next sequence until the last clue sequence. The order should not be out of sequence according to the proper sequence or steps. If the instructions are not in order, there will be an error in performing or using the instructions. The third phase is finishing. At this stage, the writer needs to re-examine the written instructions, is the order correct? Are the pictures or illustrations appropriately used? Are the words and sentences effectively and communicatively used and in accordance with the target of the instructions? If they all are appropriate, then it is published to users according to the media used.

Based on the explanation above, when viewed in terms of language, writing good instructions has several requirements, at least including (1) the communicative 
and interactive language used. This means that it is immediately understood by the reader and uses words like you and your brother; (2) does not use emotive language such as compound words or proverbs that have a figurative meaning; (3) uses appropriate words to the target community groups, and (4) the use of effective and unambiguous sentences.

When it is viewed in terms of difficulty, the instructions can be divided into (1) instructions whose steps are not graded and (2) instructions that the steps are multilevel. The fist instruction is easy to understand and easy to do. The second one is not easy to do because it has many sequences and stages. Instructions that are easy to do, such as instructions for opening a car door, consist of only three or four steps; the car door can be opened. It will be more complicated if the instructions are improved on the use of the car. Instructions for using a car usually start with instructions for opening the car door, then starting the car engine, installing a seat belt, how to hold and drive a car, how to run a car which consists of forward, backward, turn left and turn right. Each of these steps has its own sub-steps or nested steps. Therefore, it is not possible to directly drive a car within one practice, but needs more practices or goes to courses.

\section{Lesson Plan Writing Instructions}

The implementation of learning to write instructions is based on of the Minister of Education and Culture Regulation Number 22 of 2016 regarding Process Standards and the Minister of Education and Culture Regulation Number 103 of 2014 regarding Learning at the Elementary and Secondary Education levels. The regulations explain the competency standards of graduates, syllabus, and learning implementation plans. The first step that needs to be done before preparing a lesson plan is analyzing the competency standards of graduates. After analyzing the competency standards of graduates, they are then translated into a syllabus and designing a lesson plan as a direction of learning to achieve basic competencies (Endraswara, 2005).

The Minister of Education and Culture Regulation No. 22 of 2016 indicates that the preparation of a learning implementation plan contains 13 components. Then it was revised into 4 components through the Minister of Education and Culture Circular Number 14 of 2019 regarding the simplification of the learning implementation plan. Those components are (1) the preparation of a learning implementation plan with the principles of efficiency, effectiveness, and student and teacher activity-oriented; (2) thirteen components of a simple learning implementation plan according to the regulation. The core components of the regulation that must be implemented by teachers are learning objectives, learning steps, and learning assessments. The other components are complementary; (3) schools, groups of teachers of similar subjects in schools, Teacher Working Groups / Subject Teacher Deliberations, and individual teachers can freely choose, create, use, and develop implementation plan formats independent learning to the maximum extent possible for the success of students; and (4) the preparation of learning 
implementation plans can be adjusted to points 1, 2, and 3. Below are examples of preparing graduate competency standards, syllabus, and learning implementation plans.

\section{Graduate Competence Standard}

\begin{tabular}{|l|l|l|l|l|l|l|}
\hline \multicolumn{1}{|c|}{ Domain } & $\begin{array}{c}\text { Graduate } \\
\text { Competence } \\
\text { Standard }\end{array}$ & $\begin{array}{c}\text { Core } \\
\text { Competences }\end{array}$ & $\begin{array}{c}\text { Basic } \\
\text { Competences }\end{array}$ & $\begin{array}{c}\text { Scope of } \\
\text { Subject } \\
\text { Matter }\end{array}$ & $\begin{array}{c}\text { Student } \\
\text { Learning } \\
\text { Activities }\end{array}$ & $\begin{array}{c}\text { Techniques } \\
\text { and Forms of } \\
\text { Assessment } \\
\text { Instruments }\end{array}$ \\
\hline Attitude & & & & & & \\
\hline Knowledge & & & & & & \\
\hline Skills & & & & & & \\
\hline
\end{tabular}

\section{Syllabus}

Subject : : Bahasa Indonesia

Education units : : SMP Negeri Kahayangan

Class/Semester : : VIII/1

Academic year : 2020/2021

Time Allocation : 40 minutes

\begin{tabular}{|c|c|c|c|c|c|c|}
\hline $\begin{array}{c}\text { Basic } \\
\text { Competences }\end{array}$ & Topics & $\begin{array}{c}\text { Learning } \\
\text { Activities }\end{array}$ & $\begin{array}{c}\text { Indicators of } \\
\text { Competence } \\
\text { Achievement }\end{array}$ & Evaluation & $\begin{array}{c}\text { Time } \\
\text { Allocation }\end{array}$ & $\begin{array}{c}\text { Learning } \\
\text { Resources }\end{array}$ \\
\hline & & & & & & \\
\hline & & & & & & \\
\hline
\end{tabular}

\section{Lesson Plan}

Education Units : : SMP Kahayangan

Subjects : Bahasa Indonesia

Class/Semester $\quad:$ IX/1

Time Allocation $\quad: 1 \mathrm{x}$ meeting $\mathrm{x} 40$ minutes (1st meeting)

A. Core Competences

\begin{tabular}{|l|l|}
\hline Core Competences & Competency Description \\
\hline Spiritual Attitude & \\
\hline Social Attitude & \\
\hline Knowledge & \\
\hline Skills & \\
\hline
\end{tabular}

B. Basic Competency and Competency Achievement Indicators

\begin{tabular}{|l|l|}
\hline Basic Competences & Competency Achievement Indicators \\
\hline $\begin{array}{l}\text { 3.1 Identify the steps to create an } \\
\text { e-mail (Gmail) via the } \\
\text { internet/or books }\end{array}$ & \\
\hline $\begin{array}{l}\text { 4.1 } \\
\text { Write down the steps for } \\
\text { making e-amil (Gmail) } \\
\text { orally and in writing }\end{array}$ & \\
\hline
\end{tabular}

C. Purpose

1. Identify 1 example of hand washing instructions according to the Indonesian Ministry of Health. 
2. Determine the linguistic characteristics in hand washing instructions according to the Indonesian Ministry of Health.

3. Write instructions on the steps to create an e-mail (Gmail).

D. Learning Steps

\begin{tabular}{|l|l|}
\hline Activities & Activity Description \\
\hline Preliminary & \\
\hline Core & \\
\hline Closing & \\
\hline
\end{tabular}

Acknowledged by,

Namrole, June 2021

Principal

Abdi Negara, S.Pd., Gr., M.Pd.

NIP 197701302002121005

Subject Teacher

Patuh Taat, S.Pd., Gr.

NIP 19800202200202005

Assessment forms:

The assessment in the 2013 curriculum that has been changed by the Ministry of Education and Culture is an assessment consisting of attitudes, skills and knowledge. The following is an example of the three types of assessment.

1. Assessment

a. Attitude

(1) Observation Assessment

Assessment of observations based on observations of attitudes and behavior of students in participating in distance learning.

\begin{tabular}{|c|c|c|c|c|c|c|c|c|}
\hline \multirow{2}{*}{ No } & \multirow{2}{*}{ Student's Name } & \multicolumn{3}{|c|}{ Assessed Behavioral Aspects } & Total & Attitude & $\begin{array}{c}\text { Value } \\
\text { Score }\end{array}$ \\
\cline { 3 - 6 } & & Ct & Ht & Rt & Dc & & \\
\hline 1 & $\ldots \ldots \ldots \ldots \ldots \ldots \ldots \ldots \ldots . . . \ldots$ & & & & & & & \\
\hline 2 & & $\ldots$ & $\ldots$ & $\ldots$ & $\ldots$ & $\ldots$ & $\ldots$ & $\ldots$ \\
\hline
\end{tabular}

\section{Description:}

1. $\mathrm{Ct}$ : Cooperate

2. $\mathrm{Ht}$ : Honest

3. Rt : Responsibility

4. Dc : Discipline

Notes:

1. Behavioral aspects are assessed with the following criteria:

$100=$ Very Good

$75=\mathrm{OK}$

$50=$ Enough

$25=$ Less

2. Maximum score $=$ number of attitudes assessed multiplied by number of criteria $=100 \times 4=400$

3. Attitude score $=$ total score divided by the number of attitudes assessed $=275: 4=$ 68.75

4. Value code / predicate:

$75.01-100.00=$ Very Good 


$\begin{array}{lll}50.01-75.00 & =\text { Good } & \text { (B) } \\ 25.01-50.00 & =\text { Enough } & \text { (C) } \\ 00.00-25.00 & =\text { Less } & \text { (D) }\end{array}$

5. The above format can be changed according to the behavioral aspect you want to assess

a. Skills

1. Performance Assessment

Discussion Assessment Instruments

\begin{tabular}{|c|l|c|c|c|c|}
\hline No & \multicolumn{1}{|c|}{ Rated aspect } & $\mathbf{1 0 0}$ & $\mathbf{7 5}$ & $\mathbf{5 0}$ & $\mathbf{2 5}$ \\
\hline 1 & Mastery of discussion material & & & & \\
\hline 2 & Ability to answer questions & & & & \\
\hline 3 & Ability to process words & & & & \\
\hline 4 & Ability Problem solving & & & & \\
\hline
\end{tabular}

Information :

100 = Very Good

$75 \quad=\mathrm{OK}$

$50 \quad=$ Less

$25=$ Not Good

2. Portfolio Assessment A collection of all assignments that have been done by students, such as notes, homework, etc.

Assessment Instrument

\begin{tabular}{|c|c|c|c|c|c|}
\hline No & Rated aspect & 100 & 75 & 50 & 25 \\
\hline 1 & & & & & \\
\hline 2 & & & & & \\
\hline 3 & & & & & \\
\hline 4 & & & & & \\
\hline \multicolumn{6}{|c|}{ Description and Code value / predicate: } \\
\hline $85-100$ & = Very Good & & & & \\
\hline $55-84$ & $=$ Good $(\mathrm{B})$ & & & & \\
\hline $25-54$ & $=$ Enough & & & & \\
\hline $0-24$ & $=$ Less & & & & \\
\hline
\end{tabular}

Assignment

Homework

1. Students answer the questions contained in the student book

2. Students ask for parental signatures as proof that they have done their homework well

3. Students collect answers through /WA/ GC/ Siakad/ to be assessed

\section{Closing}

The skill of writing instructions is one type of skill that must be possessed by students. As required in the 2013 curriculum as the implementation of Permendikbud Number 22 of 2016 concerning Process Standards and Permendikbud Number 103 of 2014 concerning graduate competency standards, syllabus, and learning implementation plans. 
Instructional writing skills if managed properly will become 21 st century life skills. The era of globalization demands guidance in high-level technological activities. In all areas of life requires life. Moreover, technology that uses step-bystep, which are not complicated to do, then instructions are the safest and easiest way for consumers to take. Writing instructions is one of the materials that must be studied in schools in accordance with the instructions of the 2013 curriculum.

The steps that need to be taken by teachers in the preparation of learning tools are as follows, (1) analyzing graduate competency standards, (2) compiling a syllabus, and (3) compiling a learning implementation plan. The lesson plan is prepared based on the syllabus, and the syllabus is prepared based on the graduate competency standard. The lesson plan is a guide or direction for the teacher in carrying out the learning process.

\section{References}

Endraswara, Suardi. 2005. Media dan Teori Pengajaran Sastra. Yogyakarta: Buana Pustaka. Depdiknas. 2007. Menulis Surat, Iklan, dan Poster. Jakarta: Depdiknas.

Geneva-WHO. 2019. WHO guidelines on hand hygiene in health care first global patient safety challenge. Switzerland: WHO Press; 2009. Diunduh pada Juni 2021, dari http://eprints.undip.ac.id/42527/1/Bab_I-IV.pdf.

Harosid, Harun. 2017. "Kurikulum 2013 Revisi 2017". PPT GAMBARAN-UMUM-K13REVISI-2017.

Helmi, Februari 2016. Menulis Petunjuk. Gudang Ilmu. Diperoleh pada Juni 2021, dari https://ilmu-pendidikan-berbagi.blogspot.com/2016/ 02/menulis-petunjuk.html.

Suyatno. 2004. Teknik Pembelajaran Bahasa dan Sastra. Surabaya: SIC.

Sholeh, Muhammad. 2021. "Mengenal Apa Itu WBSPro dan Cara Penggunaannya". MSMuhammadSholeh.

Rachel, Scoggins. 2016. "Cara menulis petunju”. WikiHOW. Diperoleh pada 21 Juni 2021, dari https://id.wikihow.com/Menulis-Petunjuk\#aiinfo.

Rumalean, Iwan. 2014. "Penggunaan Teknik Cerita Berantai dalam Meningkatkan Kemampuan Menyimak Siswa Kelas IX SMP PGRI Mawah Kabupaten Maluku Tengah". Jurnal Ilmiah Jendela Pengetahuan, Volume 7(17), p.p 17-28, tahun 2015. Diperoleh pada Oktober 2021 melalui https://scholar.google.co.id/citations?view op=view citation \&hl=id\&user=FcxyGsAAAAAJ\&citation for view=FcxyGsAAAAAJ:2osOgN Q5qMEC.

Rumalean, Iwan. 2014. "Media Poster Sebagai Sarana Peningkatan Kemampuan Menulis Karangan Persuasi Siswa Kelas IX SMP Negeri 3 Pulau Gorom Kabupaten Seram Bagian Timur". Jurnal Tahuri, Volume 11(2), p.p 17-28, tahun 2015. Diperoleh pada Oktober 2021, melalui https://ejournal.unpatti.ac.id/ppr_tahuri.php.

Admin, MadrasahId. 2019. "Edaran Mendikbud No. 14 Tahun 2019 Tentang Penyederhanaan RPP”. Ayo-Madrasah.Id. Diperoleh pada 22 Juni 2021 dari https://www.ayomadrasah.id/2019/12/edaran-mendikbud-no-14-tahun2019.html. 